\title{
Analisis fasilitas tarif pajak penghasilan terutang ditinjau dari penghasilan bruto
}

\author{
Soko Wikardojo; Ahmad Mukoffi*; Risnaningsih; Adelsiana Lero Kaka
}

Prodi Akuntansi, Fakultas Ekonomi, Universita Tribhuwana Tunggadewi Malang

*E-mail korespondensi: unitriahmadmukoffi@gmail.com

\begin{abstract}
National development is a sustainable development related to the whole life of society, nation, and state. National development is supported by several supporting aspects, one of which is tax revenue. This research aims to find out the facility of income tax rate payable in terms of gross income. The type of research used in this research is Interpretive Qualitative data. This Study uses data collection techniques, namely interview techniques, documentation, and observation. The types of data used in this stud are primary data and secondary data. The data analysis technique used is the descriptive analysis technique. The government issued tax law number 36 of 2008 by providing an incentive for tax reduction facilities for taxpayers, as stated in article 31E. The research results show that KPRI Universitas Brawijaya Malang has implemented Article 31 E of the PPh Law Number 36 of 2008.
\end{abstract}

Keywords: Tax facility, Income tax payable, Gross income.

Abstrak

Pembangunan Nasional merupakan pembangunan berkesinambungan yang berkaitan dengan seluruh kehidupan bermasyarakat, berbangsa dan bernegara. Pembangunan nasional ditunjang oleh beberapa aspek pendukung salah satunya penerimaan pajak. Tujuan penelitian untuk mengetahui fasilitas tarif pajak penghasilan terutang ditinjau dari penghasilan bruto. Jenis penelitian yang digunakan adalah data Kualitatif Interpretif. Menggunakan teknik pengumpulan data wawancara, dokumentasi dan observasi. Serta tipe data primer dan data sekunder. Teknik analisis data yang digunakan dalam penelitian ini adalah teknik analisis deskriptif. Pemerintah menerbitkan Undang-Undang Perpajakan No. 36 Tahun 2008 untuk memberikan fasilitas pengurangan pajak bagi wajib pajak berdasarkan Pasal 31E. Hasil riset menunjukkan bahwa KPRI Universitas Brawijaya Malang telah menerapkan pasal 31E UU PPh No. 36 Tahun 2008.

Kata kunci: Fasilitas pajak, Pajak penghasilan terutang, Penghasilan bruto.

\section{PENDAHULUAN}

Pajak memiliki kekuatan besar dalam pembangunan negara sebab pajak adalah penyumbang dana terbesar (Putong et al., 2019). Berbagai upaya sudah dilakukan Pemerintah dalam memaksimalkan jumlah penerimaan pajak seperti intensifikasi pajak dan ekstensifikasi. Upaya yang dilakukan yaitu dengan memperbesar kapasitas subjek dan objek pajak dengan upaya meraih sebanyak mungkin Wajib Pajak (Ariesta \& Latifah, 2017). Salah satunya yakni mendukung UMKM semaksimal mungkin (Mukoffi \& Soebagio, 2018) Prosedur menarik pajak di Indonesia terdapat tiga macam salah satunya 
yakni Self Assasment System dan system ini mulai diterapkan di Indonesia sejak awal reformasi pajak tahun 1983. System ini juga memberikan wewenang atau kebebasan pada Wajib Pajak untuk mencatat, menghitung pajaknya, membayar serta, melaporkan pajaknya sesuai dengan Undang-Undang Perpajakan (Amri, 2019). Tugas fiskus hanya mengawasi, memberikan pelayanan serta pembinaan kepada Wajib Pajak (Rahmawati \& Achadiyah, 2013). Salah satu cara pemerintah dalam menghimpun Wajib Pajak guna memenuhi kewajiban, pajaknya dilakukan dengan melakukan penurunan tarif yang dituangkan dalam UU PPh No. 36 Tahun 2008 untuk Wajib Pajak Badan.

Pajak penghasilan ditagih dikenakan pada Wajib Pajak Orang Pribadi (WPOP) dan Wajib Pajak (WP) Badan yang mendapat ataupun memperoleh pendapatan dalam masa satu tahun pajak (Kumaratih \& Ispriyarso, 2020). Saat ini WP UMKM dengan pendapatan bruto hingga Rp 4.800.000.000 bisa memilih tarif pajak yang akan digunakan dalam menghitung tarif pajaknya (Pramesthi et al., 2020). Adapun besar tarif pajak terutang WP Badan diatur oleh UU No. 36 Tahun 2008. Dalam Pasal 31E dituliskan bahwa WP Badan dalam negeri dengan pendapatan bruto maksimal Rp $50 \mathrm{M}$ (miliyar) diberi intensif fasilitas pemotongan tarif sebesar 50\% dari tarif normal $25 \%$ sebagaimana,dimaksudkan dalam Pasal 17 ayat (1) dan ayat (2). Pada tahun 2010 Dirjen Pajak (DJP) mengeluarkan Surat Edaran DJP N0. 66/PJ/2010 sebagai kejelasan dari UU PP No. 36 Tahun 2008 pasal 31E. Peredaran Bruto WP yang memperoleh fasilitas berkisar antar Rp 4.800.000,00 dengan batas Rp 50.000.000,00. Pendapatan bruto menurut Pasal 31E adalah seluruh perolehan penghasilan selama 1 tahun pajak sebelum dikurangi biaya atau beban lain. Sebelum menghitung pajak penghasilan badan (terutang) tentu terlebih dahulu dilakukan rekonsiliasi atau koreksi fiskal yang dilakukan oleh Fiskus guna menyesuaikan laporan komersial dengan laporan fiskal. Penyebabnya karena perbedaan pengakuan antar pendapatan, beban, maupun laba.

Fasilitas pengurang tarif pajak penghasilan memberikan dampak positif bagi WP Badan sebab dapat mengurangi beban pajak atau adanya tax saving sebesar $12,5 \%$ dari tarif normal $25 \%$. Beberapa peneliti telah melakukan penelitian tentang Fasilitas tarif pajak penghasilan badan (Sejanto et al., 2018); (Amri, 2019); (Krisanti \& Dewi, 2020); (Saragih, 2013). Penelitian serupa dilakukan oleh (Morasa \& Tindagi, 2014) Sama pada penelitian sebelumnya memperoleh hasil bahwa masih ada ketidaktahuan perusahaan akan peraturan perundang-undangan $\mathrm{PPh} 36 / 2008$ pasal 31E tentang fasilitas pengurangan tarif tersebut. Adapun penelitian lain yang dilakukan oleh (Putong et al., 2019) menjukan bahwa perhitungan pajak terutang belum memanfaatkan Pasal 31E. Penelitian ini bertujuan untuk menganalisis perhitungan penghasilan badan sudahkah berpatokan pada UU Perpajakan No. 36 Tahun 2008.

Dari beberapa penjelasakan diatas membuat peneliti tertarik untuk melaksanakan penelitian lebih lanjut tentang Fasilitas pajak pasal 31E dikarenakan banyaknya UMKM dan Koperasi yang belum memanfaatkan Fasilitas Tarif Pajak tersebut maka peneliti melakukan penelitian bagaimana "Analisis fasilitas tarif pajak penghasilan terutang jika ditinjau dari penghasilan bruto”.

\section{LANDASAN TEORI}

\section{Teori pajak}

Undang-Undang Nomor 28 Tahun 2007 pasal 1 mengartikan pajak demikian: Pajak didefenisikan sebagai kontribusi yang wajib harus diberi kepada negara dan dianggap sebagai utang orang pribadi ataupun badan, sifat pajak itu sendiri memaksa, harus berlandaskan pada Undang-Undang, serta tidak secara langsung memperoleh imbalan, pajak digunakan untuk kemakmuran dan kesejahteraan rakyat (Jeni \& Ahmad, 2015). 
Pajak Menurut KEMENKEU DJP dalam buku dengan judul Lebih Dekat Dengan Pajak (Pajak, 2013). Didefenisikan pajak sebagai penerimaan atau sumber yang sangat penting dalam menunjang Kas Negara, tanpa pajak maka kegiatan negara akan terganggu atau tidak dapat dilaksanakan. (Sulastyawati, 2020) Pajak dipakai untuk membiayai pengeluaran. Terdapat beberapa fungsi pajak, yaitu : Fungsi Budgeter, dan Fungsi Regulerend (Mardiasmo, 2018). Pendapat (Rahayu et al., 2019) tentang Pajak penghasilan yakni pajak atas penghasilan yang dihasilkan dengan pengenaan pajak secara bertahap berdasarkan jangka waktu pajak. Pajak penghasilan yang dikemukakan (Permatasari et al., 2012) yakni pajak yang berkaitan dengan segala pekerjaan yang berpotensi dilakukan pemotongan pajak serta dibayarkan oleh pihak tertentu. Dapat ditarik kesimpulan PPh adalah pajak yang dipotong dari WPOP maupun WP Badan atas perolehan penghasilannya berdasarkan Undang-Undang.

\section{Teori peredaran bruto}

Peredaran bruto atau penghasilan bruto dijelaskan dalam SE-02/PJ/2015 adalah total seluruh pendapatan yang diperoleh dari kegiatan usaha maupun di luar usaha setelah melakukan beberapa pengurangan. PPh menurut UU No. 36 Tahun 2008 merupakan penghasilan berbentuk bunga simpanan, dan simpanan lainnya, obligasi ataupun surat berharga negara, serta bunga simpanan yang diberikan kepada anggota koperasi perseorangan, dan lain sebagainya (Noviari, 2014). Tarif pajak biasanya berbentuk persentase (\%) dipakai saat menghitung seberapa besaran pajak terutang yang harus disetorkan(Supramono \& Damayanti, 2011). Rumus PPh terutang dengan fasilitas yakni $\mathrm{PPh}$ Terutang $=50 \% \times 25 \% \times \mathrm{PKP}$.

\section{Undang-Undang PPh Nomor 36 Tahun 2008}

Undang-Undang perpajakan di Indonesia sudah mengalami empat kali reformasi terakhir tahun 2008 yaitu UU PPh No. 36 Tahun 2008 yang berlaku hingga saat ini. Pada Pasal 31E membahas tentang WP Badan. Fasilitas tarif pajak atas PKP sejumlah 50\% dari tarif biasa $25 \%$ diperuntukan bagi WP badan dalam negeri dengan penghasilan bruto tidak lebih dari Rp 50.000.000,00. Hingga tahun 2010 tanggal 24 Mei kejelasan akan pasal 31E dimana DJP menerbitkan SE DJP Nomor 66/PJ/2010 dengan isi : 1) Pelaksanaan dengan metode self assessment pada pengisian SPT. 2) Penghasilan bruto tidak melebihi Rp 50 Miliyar. 3) Segala perolehan penghasilan dari kegiatan usaha maupun diluar usaha setelah dilakukan pengurangan beban. 4) tidak wajib bagi WP berpenghasilan bruto dibawah Rp 4,8 M.

Riset terdahulu oleh (Sejanto et al., 2018) Hasil dari penelitian tersebut menunjukan CV Venus Kumersot Raya belum menggunakan fasilitas pengurangan perhitungan PPh yang sesuai dengan Pasal 31E dalam menghitung PPh terutangnya. (Amri, 2019) Hasil penelitian peneliti yakni perhitungan, penetapan, penyetoran serta pelaporan pajak penghasilan PT. Artamas Prima Nusantara telah berdasarkan pada Undang-Undang Perpajakan dan Peraturan Pemerintah No. 23 Tahun 2018. Analisis Perhitungan PPh Badan pada PT Redsun Lestari Tahun 2018 oleh (Krisanti \& Dewi, 2020). Hasil dari penelitian ini menunjukan koreksi fiskal yang disusun perusahaan belum sesuai dengan ketentuan perpajakan karena terdapat akun yang belum dilakukan koreksi fiskal. Hal ini menyebabkan perusahaan belum melakukan perhitungan $\mathrm{PPh}$ berdasar Undang-Undang Perpajakan pasal 31E dikarenakan kesalahan koreksi fiskal.

\section{METODE}

Jenis Penelitian yang dipakai penelitian yaitu menggunakan penelitian kualitatif interpretif. Kualitatif interpretif dapat diartikan sebagai pendekatan sosial dengan berdasarkan pada pengalaman objek penelitian secara detai (Abdelsamie et al., 2014). 
Dengan interpretif peneliti akan mencari banyak informasi serta melihat kejadian ataupun fenomena dari pengalaman objek penelitian, pandangan serta pengalaman objek penelitian merupakan awalan dalam penelitian ini yakni dengan cara mencari informasi ataupun jawaban atas setiap periswita sosial/budaya (Chriswindari, 2018) . Sifat Interpretif terdapat pendapat, saran, kesan, maupun pandangan sehubungan dengan penafsiran tersebut (Muslim, 2016). Penelitian interpretif termasuk dalam tipe penelitian yang secara menyeluruh berusaha menceritakan serta menguraikan maksud dari objek penelitian secara mendetail (Djasuli, 2017) .

Data primer dan data sekunder merupakan jenis data yang diterapkan dalam tesis ini. Sedangkan sumber data memakai data kualitatif dan kuantitatif. Tempat melekatnya subjek penelitian maupun data bisa dalam bentuk orang, benda, tempat dan lain sebagainya merupakan pengertian Sumber data Sumber data penunjang dalam penelitian ini yakni narasumber atau informan dengan peran sangat penting tidak hanya sebagai responden akan tetapi sebagai pemilik informasi penting. Hal ini sepadan dengan julukan informan yakni orang pemberi informasi, sumber informasi serta sumber data. Untuk memperoleh Sumber data utama maka peneliti melakukan wawancara kepada salah satu karyawan atau koperasi bagian Akuntansi (narasumber atau informan).

Penelitian dilaksanakan di Koperasi Pegawai Republik Indonesia Universitas Brawijaya Malang yang berlokasi di Jl.MT Haryono No.169, Dinoyo, Lowokwaru, Ketawanggede, Kec. Lowokwaru Kota Malang. Tiga tahapan pengumpulan data, diantaranya adalah: 1) Observasi dikatakan sebagai proses pengamatan dengan cara peneliti mengamati secara langsung objek penelitiannya guna memperoleh informasi ataupun data. 2) Wawancara, Metode ini bertujuan mendapatkan data dalam bentuk penjelasan dari Perusahaan yang sudah dialami. Wawancara digunakan dalam bentuk wawancara terstruktur. 3) Dokumentasi, Metode Dokumentasi dilakukam dengan cara mengambil arsipan data dari berbagai sumber dokumentasi, seperti data dari pengumpul data yang dipublis secara umum pada masyarakat. Contohnya seperti sejarah dan strukstur organisasi perusahaan.

Teknik analisis data merupakan tahapan penting karena analisis data akan memudahkan peneliti memecahkan masalah penelitian. Analisis yang dipakai yaitu Analisis Deskriptif. Untuk menguji kredibilitas peneliti memakai triangulasi, dilakukan dengan memeriksa sumber data dengan berbagai sistem dan waktu. Dua jenis triangulasi yang peneliti terapkan yaitu pertama triangulasi sumber data dengan cara mencari fakta ataun kebenaran informasi dengan macam-macam prosedur dan sumber data diperoleh. Misalnya, diluar langkah wawancara dan observasi, peneliti juga dapat mengaplikasikan observasi terlibat, dokumen-dokemen tertulis, catatan resmi, gambar ataupun foto dan lainnya. Setiap cara tentu saja menghasilkan informasi bukti data dan pandangan yang berbeda. Kedua pengujian teknik analisis Triangulasi metode dilaksanakan dengan memyamakan data dan informasi dengan prosedur yang berbeda yakni memeriksa balik kebenaran suatu informasi dan data dengan alat dan waktu yang berbeda pula.

\section{HASIL DAN PEMBAHASAN}

Sebelum diterapkan peraturan terbaru perhitungan pajak terutang sebelumnya memakai skema tarif progresif berdasarkan yang tercantum dalam Pasal 17 Ayat $1 \mathrm{UU}$ $\mathrm{PPh}$ No.36 Tahun 2008. Maksudnya, beban tarif pajak akan semakin tinggi sesuai dengan bertambahnya jumlah perolehan penghasilan yang merupakan dasar dikenakan pajak. Penerapan tarif progresif merupakan bentuk perwujudan salah satu asas pajak yakni asas keadilan. Dimana orang dengan pendapatan tinggi akan menyetor pajak lebih tinggi begitupun sebaliknya orang berpenghasilan rendah akan membayar pajak lebih sedikit. 
Persentase tarif pajak yang diberikan/dibebankan pada WP dalam negeri berdasarkan PPh Pasal 17 sebesar 28\%. Pada Ayat 2(a) disebutkan juga per tahun 2010 tarif PPh WP badan diubah menjadi $25 \%$. WPOP dan WP badan dengan pendapatan bruto diatas Rp 4,8 M wajib menyelenggarakan pembukuan.

Kemudahan atas dilirisnya PP No. 23 Tahun 2018 tidak hanya berkaitan dengan penurunan tarif sebesar $0,5 \%$ akan tetapi juga memberi pilihan bagi UMKM maupun Koperasi untuk menentukan sendiri ingin menggunakan PP No 23 Tahun 2018 tarif $0.5 \%$ atau memilih tarif normal pasal 17. Tentu saja pilihan ini menjadi jalan keluar bagi pengusaha yang mendapat laba profit keuntungan rendah sebab dapat secara langsung menggunakan tarif normal pasal 17.

Tabel 1. Laporan perpajakan

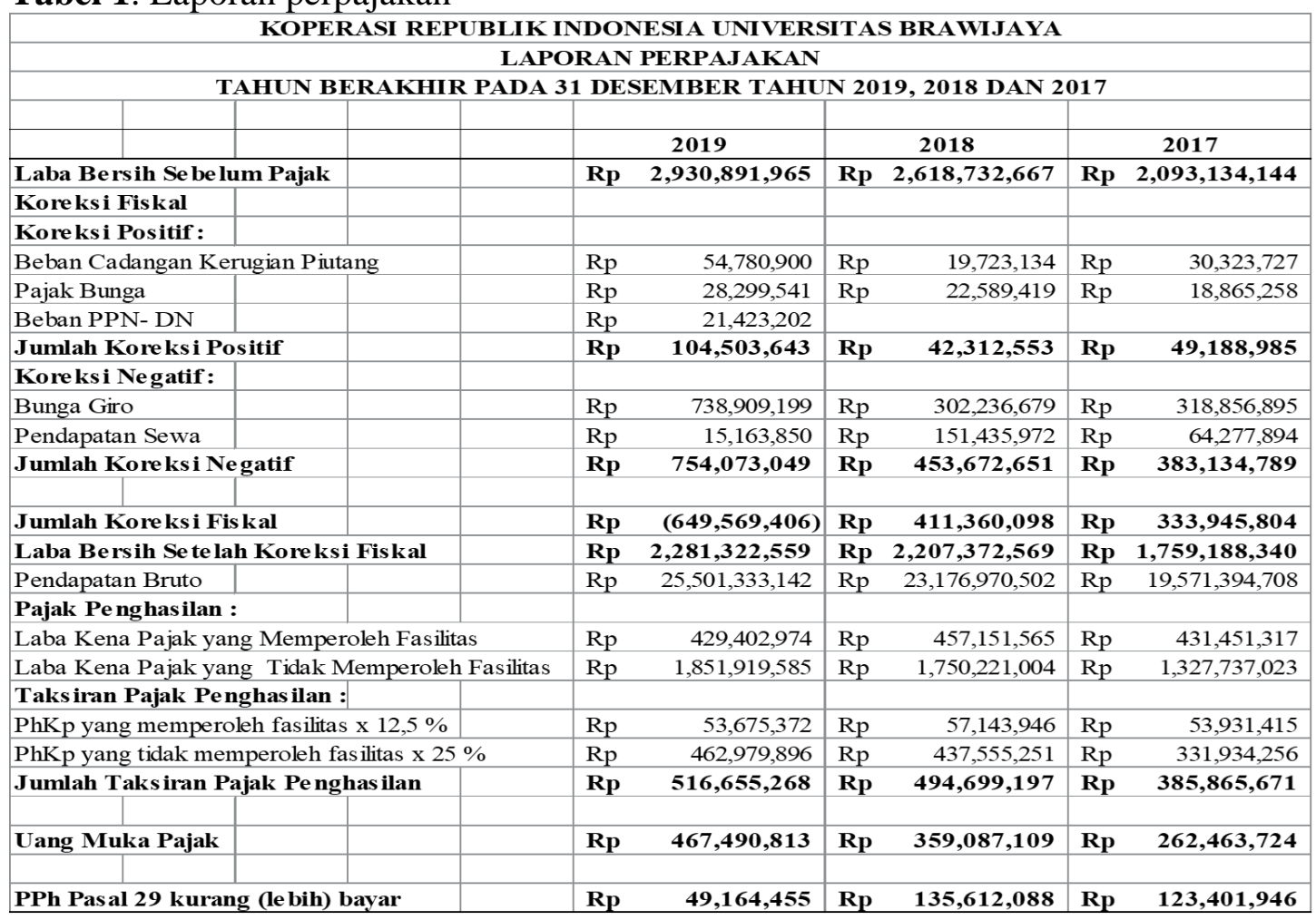

Sumber : Data diolah, 2021

Koreksi fiskal terlebih dahulu dilakukan sebelum masuk pada perhitungan $\mathrm{PPh}$. Sebab, terdapat perbedaan pengakuan pada pendapatan maupun biaya menurut Standar Akuntansi dan Standar Perpajakan. Perbedaan tersebut kemudian disatukan dengan jembatan penghubung yaitu rekonsiliasi biasa dikenak dengan koreksi fiskal juga. Tahapan awal perhitungan pajak penghasilan terutang dimulai dari dilakukan koreksi fiskal setelah memperoleh hasil laba bersih setelah koreksi fiskal maka selanjutnya akan langsung masuk pada perhitungan $\mathrm{PPh}$, dilihat dari penghasilan kotor Koperasi KPRI UB Malang sudah beromzet diatas Rp 4,8 M sehingga perhitungan pajak penghasilan terutang menggunakan skema tarif normal berdasarkan Pasal 31 E.

Dari data yang diperoleh diketahui pendapatan usaha Koperasi KPRI Universitas Brawijaya Malang per tahun 2019 sebesar Rp 23.022.422.537. Dalam UU/36/2008 dijelaskan WPOP maupun WP badan dengan penghasilan bruto diatas angka Rp 4,8 M dengan batas maksimal $\mathrm{Rp} 50 \mathrm{M}$ tidak bisa menggunakan tarif $\mathrm{PPh} 0,5 \%$.Untuk WP badan berpenghasilan bruto tidak melebihi Rp 50.000.000.000 beroleh keistimewaan fasilitas tarif PPh dari 25\% menjadi 12,5\%. Berikut ini perhitungan peredaran bruto yang 
mendapatkan Fasilitas Pajak di KPRI Universitas Brawijaya Malang per Tahun 2019. PKP yang Memperoleh Fasilitas dan PPh yang Memperoleh Fasilitas dengan perhitungan sebagai berikut ; 1) PKP dengan Fasilitas = Rp 4.800.000 : Pendapatan Bruto x Laba Setelah Koreksi Fiskal $=$ Rp 4.800.000 : Rp 25.501.333.142 x Rp 2.281.322.559 = Rp 429.402.974. Setelah diperoleh PKP dengan fasilitas masuk pada perhitungan $\mathrm{PPh}$ dengan fasilitas. 2) $\mathrm{PPh}$ dengan fasilitas $=\mathrm{PKP} \times 25 \% \times 50 \%=\mathrm{Rp} 429.402 .974 \times 25 \%$ x $50 \%=\mathrm{Rp} 53.675 .372$. Setelah melakukan perhitungan penghasilan kena pajak maka diperoleh hasil Rp 53.675.372. Selanjutnya masuk pada perhitungan PKP yang Tidak Memperoleh Fasilitas dan PPh yang Tidak Memperoleh Fasilitas berikut perhitungannya: 1) PKP tanpa Fasilitas $=R p$ 2.281.322.559 $-\mathrm{Rp} 429.402 .974=R p$ 1.851.919.585. 2) PPh tanpa Fasilitas = PKP x 25\% =Rp 1.851.919.585 x 25\% = Rp 462.979.896. Perhitungan tersebut dapat diketahui jumlah pajak penghasilan terutang KPRI Universitas Brawijaya Malang setelah mendapat Fasilitas sebesar Rp 53.675.372 + Rp 462.979.896 = Rp 516.655.268. Fasilitas yang diberikan PKP pasal 31E memiliki dampak positif yakni mengurangi beban pajak bagi WP.

Insentif fiskal fasilitas pengurangan tarif pasal 31E yang diberi Pemerintah jika dimanfaatkan oleh UMKM maupun Koperasi merupakan keuntungan bagi WP (Sari, 2018). Dengan adanya pemanfaatan fasilitas beban pajak terutang, akan memberikan keuntungan bagi wajib pajak dalam memenuhi kewajiban perpajakannya, dalam hal ini koperasi Universitas Brawijaya telah melakukan pemanfaatan pasal $31 \mathrm{E}$ dengan pembayaran yang kecil dibandingkan tanpa memanfaatkan fasilitas pengurangan tarif pajak (Krisanti \& Dewi, 2020). UMKM dan Koperasi yang tidak mampu memnafaatkan fasilitas pengurangan tarif pajak dimana dalam perhitungan pajak belum sesuai UndangUndang Pajak masih ditemukan adanya kesalahan dalam koreksi fiskal serta klasifikasi tarif yang masih salah, sehingga berdampa terhadap beban pajak yang tinggi (Morasa \& Tindagi, 2014; Putong et al., 2019; Sejanto et al., 2018). Perhitungan fasilitas pengurangan tarif pajak untuk menentukan beban pajak terutang sangat mudah untuk dipahami oleh wajib pajak jika umkm selalu mengikuti perkembangan informasi tentang peraturan perpajakan terbaru, sehingga akan mempermudah dalam menghitung pajak terutang (Inasius, n.d., 2012).

\section{KESIMPULAN DAN SARAN}

\section{Kesimpulan}

Setelah peneliti menganalisis dan mengemukakan pembahasan diatas maka ditarik sebuah kesimpulan bahwa Koperasi KPRI Universitas Brawijaya Malang telah melakukan perhitungan PPh terutang berpatokan pada Undang-Undang Perpajakan No. 36 Tahun 2008 Pasal $31 \mathrm{E}$ tentang perolehan fasilitas pengurangan tarif pajak $\mathrm{PPh}$. Sebab Koperasi KPRI Universitas Brawijaya Malang sudah beromzet diatas 4,8 M serta sudah melakukan pembukuan. Peraturan perpajakan UMKM terbaru yang diterbitkan pemerintah yakni Peraturan Pemerintah No. 23 Tahun 2018 ini lebih ditujukan bagi UMKM ataupun pengusaha dengan omzet penghasilan bruto kurang dari Rp 4,8 M.

\section{Saran}

Berdasarkan hasil riset dan segala keterbatasan dalam penelitian ini maka dapat diambil saran yakni peneliti selanjutnya dapat lebih luas objek penelitianya dan variabel yang berbeda serta diharapkan penelitian ini menjadi bahan referensi terutama yang berkaitan dengan fasilitas pajak. 


\section{DAFTAR PUSTAKA}

Abdelsamie, M. A. A., dkk. (2014). The franchising relationship quality: It is important? Procedia - Social and Behavioral Sciences, 1(2), 24-27.

Amri, F. (2019). Analisis perhitungan dan penetapan pajak penghasilan atas wajib pajak yang memiliki peredaran bruto tertentu serta pelaporannya pada PT. Artamas Prima Nusantara. Tirtayasa Ekonomika, 14(1), 129. https://doi.org/10.35448/ jte.v14i1.5416

Ariesta, R. P., \& Latifah, L. (2017). Pengaruh kesadaran wajib pajak , sanksi perpajakan , sistem administrasi perpajakan modern , pengetahuan korupsi , dan tax amnesty terhadap kepatuhan wajib pajak. Akuntansi Dewantara, 1(2), 173-187.

Chriswindari, B. R. (2018). Analisis resepsi komunitas stand up comedy salatiga terhadap video unggahan beda media tentang stand up comedy joshua suherman: Studi Analisis Resepsi Stuart Hall. 15-16.

Djasuli, M. (2017). Paradigma interpretif pada riset akuntansi ( sebuah opini : peneliti pemula tidak terjebak dalam penelitian minimalis akuntansi). Jurnal Pamator, 10(2), 97-106.

Inasius, F. (n.d.). Analisis Pajak penghasilan bagi wajib pajak badan usaha kecilmenengah di Indonesia. 9, 673-682.

Jeni, S., \& Ahmad, D. (2015). Perpajakan untuk praktisi dan akademisi. Empatdua Media.

Krisanti, W., \& Dewi, D. (2020). Pajak Penghasilan Badan pada PT Redsun Lestari Tahun 2018 Jurnal Multiparadigma Akuntansi Tarumanagara, 2(April), 930-935.

Kumaratih, C., \& Ispriyarso, B. (2020). Pengaruh kebijakan perubahan tarif PPH final terhadap kepatuhan wajib pajak pelaku UMKM. Jurnal Pembangunan Hukum Indonesia, 2(2), 158-173. https://doi.org/10.14710/jphi.v2i2.158-173

Mardiasmo. (2018). Perpajakan edisi terbaru 2018(tax and taxation). Andi.

Morasa, J., \& Tindagi, R. (2014). Analisis perhitungan pajak penghasilan badan pada Pt. Golden Mitra Inti Perkasa. Jurnal Riset Ekonomi, Manajemen, Bisnis dan Akuntansi, 2(2), 1067-1076. https://doi.org/10.35794/emba.v2i2.4487

Mukoffi, A., \& Soebagio, A. S. (2018). Pengembangan usaha mikro kecil dan menengah telor asin di Kelurahan Mojolangu Kota Malang. JAPI (Jurnal Akses Pengabdian Indonesia), 3(2), 98. https://doi.org/10.33366/japi.v3i2.1052

Muslim. (2016). Varian-Varian Paradigma, pendekatan, metode, dan jenis penelitian dalam ilmu komunikasi. Wahana, 1, No.10(10), 77-85.

Noviari, N. (2014). Analysis of the implementation of Government Regulation No. 46 2013 in the calculation of PT ABC's income tax payable 2013/2014.The Indonesian Accounting Review,4(02),175. https://doi.org/10.14414/tiar.v4i02.333

Permatasari, A. I. S., Kumadji, S., \& Effendi, I. (2012). Analisis perhitungan, pemotongan, penyetoran, dan pelaporan pajak penghasilan (PPH) Pasal 21 atas karyawan tetap PT. Petrokimia Gresik. Psychology Applied to Work: An Introduction to Industrial and Organizational Psychology, Tenth Edition Paul, 53(9), 1689-1699.

Pramesthi, I. G. A. O. N., Hardika, N. S., \& Suta, W. P. (2020). Comparative analysis of the application of corporate income tax between based on the income tax law number 36 of 2008 with government regulation number 23 of 2018 on CV. ITM. Journal of Applied Sciences in Accounting, Finance and Tax, 3(2), 83-90. https://doi.org/10.31940/jasafint.v3i2.2119 
Putong, I. H., Limpeleh, R. H. S. D., Kaunang, A. M., Awuy, R., \& Manginsela, A. (2019). Analysis of income tax calculation based on law number 36 of 2008 At fisheries collector traders. Scientific Research Journal, VII(VI), 7-14. https://doi.org/10.31364/scirj/v7.i6.2019.p0619658

Rahayu, T., Alamanda, A. R., \& Rum, I. A. (2019). Tinjauan atas pelaksanaan pemungutan, penyetoran, dan pelaporan pajak pertambahan nilai (PPN) Pada Pt. Mainest Gaya Kreatif. Ekonomi Bisnis Terapan, 15(1), 2.

Rahmawati, D., \& Achadiyah, B. N. (2013). Analisis perbedaan tingkat kepatuhan wajib pajak penerapaN PP No . 46 Tahun 2013 (Studi pada KPP Pratama Pasuruan ). Jurnal Akuntansi Aktual, 3(46), 207-214.

Saragih, F. (2013). Akuntansi Pajak, Pajak Penghasilan Badan, Laporan Laba Rugi. Universitas Muhammadiyah Sumatera Utara, 53(9), 1689-1699.

Sari, R. (2018). Kebijakan insentif pajak bagi usaha mikro, kecil, dan menengah. info singkat bidang ekonomi dan kebijakan publik, 10(12), 19-24.

Sejanto, T. W., Elim, I., \& Tirayoh, V. Z. (2018). Analisis perhitungan, pencatatan dan pelaporan pajak penghasilan Pasal 25 Pada CV. Venus Kumersot Raya. Going Concern: Jurnal Riset Akuntansi, 13(02), 464-475. https://doi.org/10.32400/ gc.13.02.19644.2018

Sulastyawati, D. (2020). Bagi kesejahteraan rakyat. Jurnal Sosial Dan Budaya Syar-I, 7(10), 119-128.

Supramono, \& Damayanti. (2011). Perpajakan Indonesia: mekanisme dan pehitungan (Rosalana).

Undang-Undang Republik Indonesia Nomor 36 Tahun 2008 Tentang Pajak Penghasilan 